\title{
MORPHOMETRIC STUDY OF DRY HUMAN OCCIPITAL BONE AND
} ITS CLINICAL RELEVANCE

\section{Jessy Rose George ${ }^{* 1}$,Thomas Francis ${ }^{2}$, Joseph Francis ${ }^{2}$, Jeffy Elizabeth Samuel ${ }^{2}$.}

${ }^{1}$ Associate Professor, Department of Anatomy, Government Medical College, Kozhikode, Kerala, India.

${ }^{2}$ Department of Anatomy, Government Medical College, Kozhikode, Kerala, India.

\section{ABSTRACT}

Background: Anomalies of craniovertebral junction (CVJ) are of interest both to an anatomist as well as to the clinicians because many of these deformities produce clinical symptoms. The stability of this CVJ depends largely on the morphometric parameters of the occipital condyles (OCs). Most of the surgical approaches such as, the lateral trans-jugular approach, trans-tubercular approach and transcondylar approach require resection of the condyles.

Materials and methods: The measurements of 30 occipital condyle length, width, height, Size and the anterior and posterior intercondylar distances, Distance between the anterior tip of OC \& Basion, Distance between the posterior tip of OC \& Opisthion, Anterior intercondylar distance (AID), Posterior intercondylar distance (PID), non-metric parameters including Shape was done.

Results: Mean length, width and height of the occipital condyle were found to be 23.2, 12.39 and $9.16 \mathrm{~mm}$ on the right and 23.43, 12.31 and $8.95 \mathrm{~mm}$ on the left respectively. The anterior and posterior intercondylar distances were 21.28 and $40.61 \mathrm{~mm}$ respectively.

Conclusion: The occipital condyles are integral part of neck and base of the skull. In the present study an effort was made to measure various parameters related to occipital condyle. The data may be used as a morphometric data base for posterior and lateral approaches to the craniovertebral junction by neurosurgeons and orthopaedicians.

KEY WORDS: Occipital condyles, morphometry, Index, Craniovertebral junction.

Address for Correspondence: Dr. Jessy Rose George, Associate Professor, Department of Anatomy, Government Medical College, Kozhikode, Kerala, India. E-Mail: jessyrose@gmail.com

Access this Article online

Quick Response code

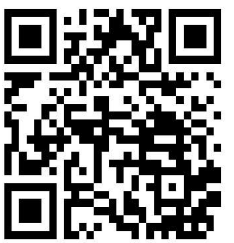

DOI: 10.16965/ijar.2018.447

\begin{tabular}{|l}
$\begin{array}{c}\text { International Journ } \\
\text { ICV for 2016 } \\
\mathbf{9 0 . 3 0}\end{array}$ \\
$\begin{array}{l}\text { ISSN (E) 2321- } \\
\text { https://w } \\
\text { Dol-Prefix: http }\end{array}$ \\
Art \\
Received: 16 Dec 2018 \\
Reer Review: 17 Dec 2018 \\
Revised: None
\end{tabular}

Journal Information

Revised: None

\section{information}

nal of Anatomy and Research 
of anterior one-third and posterior two-thirds. and is surrounded superiorly by the jugular tubercle, superlaterally by the jugular foramen, laterally by the sigmoid sinus. The location of intracranial orifices of the $\mathrm{HC}$ might vary. The location of intracranial orifices of the $\mathrm{HC}$ is important during condylectomy. Two dorsally located intracranial orifice of the HC may complicate and limit the condylectomy procedure [3].

A lateral approach during craniovertebral surgery requires resection of the occipital condyles. Hence, the morphology of the occipital condyles and their facets is important clinically. Thorough anatomical knowledge of the anomalies of the occipital condyles may be important while performing surgery and interpreting neuro-investigative procedures. Most suitable surgical techniques are to be established for a careful planning mainly based on the morphometric analysis of the foramen magnum and the occipital condyles [4].

The condylar drilling is an important step in the TCA, and the important question is how much of Occipital Condyle can be removed without damaging nearby structures and causing craniocervical instability $[5,6]$. Hence, the knowledge of the length, width and thickness of the $\mathrm{OC}$, shape of the condyle, and its articular facet will help the surgeons to decide the extent of bone that can be removed. Therefore, the present study was conducted to have a proper database regarding the morphometric parameters of occipital condyle.

\section{MATERIALS AND METHODS}

The present study is an observational, cross sectional, descriptive in nature using thirty adult dry human occipital bone. All of them were dry and free from deformity and fully ossified. All the skulls were obtained from Department of Anatomy, Government Medical College, Kozhikode. The equipment's used for the purpose of study include Vernier calliper's, Measuring scale, Digital photography equipment. The following parameters of occipital condyle were measured on both right and left sides:

1. The length of occipital condyle was measured between the distance from anterior tip of occipital condyle to posterior tip of occipital condyle, 2 . The width of occipital condyle was noted by midpoint of left margin and right margin of occipital condyle), 3 . The height of occipital condyle (noted by midpoint of upper and lower lip), 4. Anterior intercondylar distance (distance between the anterior tips of the right and left occipital condyles), 5. Posterior intercondylar distance (distance between the posterior tips of the right and left occipital condyles), 6. Distance between the anterior tip of occipital condyle and basion, 7. Distance between posterior tip of occipital condyle and opisthion, 8. Intercondylar distance: Anterior intercondylar distance (AID), 9. shapes of occipital condyle, 10. Occipital condyle index, 11. Hypoglossal canal length, 12. Diameter of hypoglossal canal. All parameters were measured using a calliper accurate to $0.01 \mathrm{~mm}$ for linear measurements.

Fig. 1: Morphometric measurements of occipital condyle.

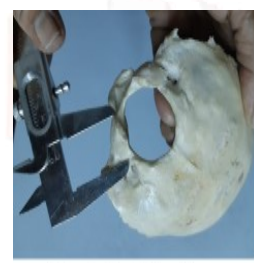

A. Length of occipital condyle

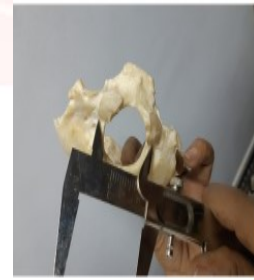

Posterior intercondylar distance

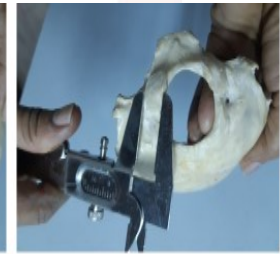

B. Width of occipital condyle

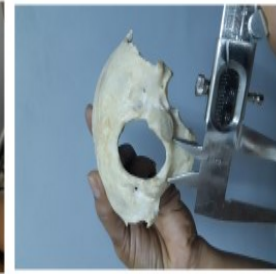

E. Auterior intercondylar distance

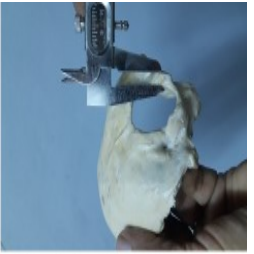

C. Height of occipital condyle

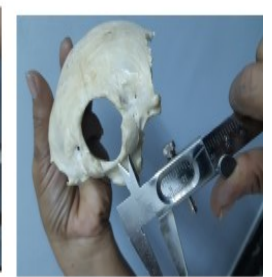

F. Distance between the anterior tip of $O C$ and basion
Fig. 2: Morphometric measurements of hypoglossal canal and foramen magnum.

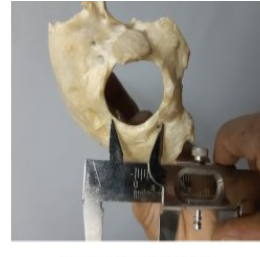

G. Distance biw the anterio tip of $O C$ and Opisthio

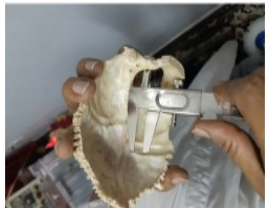

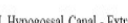
S.Hppogossal Canal - Ex

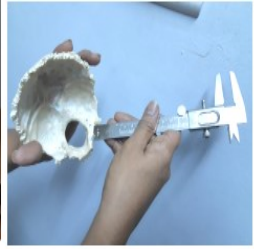

H. Hypogossal Canal - Lenengit

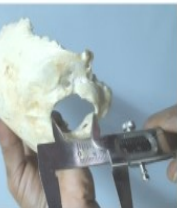

KForamen Magnum -Sagittal diamet

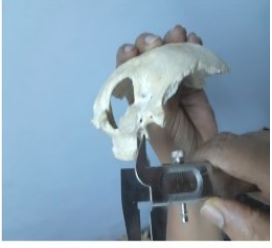
orifice diamete

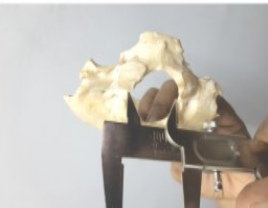

L. Foramen Magnum.
Transverse dianneter 
Statistical analysis: The data obtained was expressed as Mean and standard deviation and was analysed for statistical significance using SPSS version 16. $p$ value less than 0.05 was considered the level of significance.

\section{RESULTS}

Measurements of occipital bone such as length of occipital condyle, width of occipital condyle, height of occipital condyle, posterior intercondylar distance, anterior intercondylar distance and distance between the anterior tip of occipital condyle and basion was shown in Figure-1.

The distance between the anterior tip of occipital condyle and opisthion, length of hypoglossal canal, intra cranial orifice diameter of hypoglossal canal, Extra cranial orifice diameter of hypoglossal Canal, Sagittal diameter of Foramen Magnum and Transverse of Foramen Magnum are shown in Figure-2.

The total length of occipital condyle in the present study ranged from $17.9 \mathrm{~mm}$ to $34.0 \mathrm{~mm}$ on the left side and $18.0 \mathrm{~mm}$ to $33.5 \mathrm{~mm}$ on the right side (table-1) with mean value $23.43 \mathrm{~mm}$ and $23.22 \mathrm{~mm}$ and standard deviation of 3.57 and 3.49 respectively, which was statistically insignificant $(t=0.14, p=0.44)$.

The width was more on the right occipital condyle compared to those on the left as shown in table2 but, was insignificant statistically $(t=0.19$, $p=0.42$ ). Increased height was seen on right occipital condyle compared to those on the left as shown in table- 3 but, was statistically insignificant ( $t=0.47, p=0.32$ )

Higher occipital condylar index was noticed in the right occipital condyle (table-4) but was insignificant statistically. $(t=0.19, p=0.42)$.

Table 1: Length of right and left occipital condyle

\begin{tabular}{|c|c|c|}
\hline Parameter & Right & Left \\
\hline Range & $18.0-33.5 \mathrm{~mm}$ & $17.9-34.0 \mathrm{~mm}$ \\
\hline Mean & $23.22 \mathrm{~mm}$ & $23.43 \mathrm{~mm}$ \\
\hline S.D. & 3.49 & 3.57 \\
\hline
\end{tabular}

Table 2: Width of right and left occipital condyle.

\begin{tabular}{|c|c|c|}
\hline Parameter & Right & Left \\
\hline Range & $11 \mathrm{~mm}-15 \mathrm{~mm}$ & $11 \mathrm{~mm}-13.9 \mathrm{~mm}$ \\
\hline Mean & $12.39 \mathrm{~mm}$ & $12.31 \mathrm{~mm}$ \\
\hline S.D. & 1.17 & 0.98 \\
\hline
\end{tabular}

Table 3: Height of right and left occipital condyle.

\begin{tabular}{|c|c|c|}
\hline Parameter & Right & Left \\
\hline Range & $6.8-10.1 \mathrm{~mm}$ & $6.1-9.9 \mathrm{~mm}$ \\
\hline Mean & $9.16 \mathrm{~mm}$ & $8.95 \mathrm{~mm}$ \\
\hline S.D. & 1.07 & 1.16 \\
\hline
\end{tabular}

Table 4: Occipital condylar index.

\begin{tabular}{|c|c|c|}
\hline Parameter & Right & Left \\
\hline Range & $34.3-83.3 \mathrm{~mm}$ & $35.2-77.6 \mathrm{~mm}$ \\
\hline Mean & $54.42 \mathrm{~mm}$ & $53.63 \mathrm{~mm}$ \\
\hline S.D. & 10.5 & 9.09 \\
\hline
\end{tabular}

\section{DISCUSSION}

Configuration and size of the Occipital condyle, Hypoglossal canal \& foramen magnum play an important role in the pathophysiology of various disorders of the craniovertebral junction. Thus, a fundamental knowledge of normal anatomy and basic craniometric measurements for assessing craniovertebral relations is important to the clinician who diagnose this region and the surgeon who operates on this anatomy. In the present study, the mean length of occipital condyles was found to be mean of $23.2 \mathrm{~mm}$ on right and $23.43 \mathrm{~mm}$ on left sides respectively. Similar study carried out by Avci E et al [5], who reported the length as of occipital condyle to be $22.61 \pm 2.3$ on right and $22.36 \pm 2.3$ on left respectively.

The mean of width of occipital condyle was found to be $12.39 \mathrm{~mm}$ on right and $12.31 \mathrm{~mm}$ on left sides respectively. This measured width is comparable with the results obtained by Avci $\mathrm{E}$ et al [5] who reported the width as $12.2 \pm 1.2 \mathrm{~mm}$ on right and $12.4 \pm 1.5 \mathrm{~mm}$ respectively on left side. The height of occipital condyle was found to mean of $9.16 \mathrm{~mm}$ on right and $8.95 \mathrm{~mm}$ on left sides respectively. This measured height is approximate to the result obtained by Naderi $S$ et al. and Fathi $Z$ et al. $[7,8]$ who reported the height as $9.2 \pm 1.4 \mathrm{~mm}$ on right and $9.2 \pm 1.3 \mathrm{~mm}$ on left sides respectively.

The anterior and posterior intercondylar distances were found to be $21.28 \mathrm{~mm}$ and 40.61 $\mathrm{mm}$ respectively. The mean Basion was found to mean of $12 \mathrm{~mm}$ on right and $11.81 \mathrm{~mm}$ on left sides respectively, with SD of 0.78 and 0.79 , which is statistically insignificant. The mean Opisthion was found to mean of $28.77 \mathrm{~mm}$ on 
right and $28.95 \mathrm{~mm}$ on left sides respectively, with SD of 1.48 and 1.42 , which is also statistically insignificant. These are in line with the previous reports $[9,10]$

The mean Occipital condyle index was found to mean of $54.42 \mathrm{~mm}$ on right and $53.63 \mathrm{~mm}$ on left sides respectively, with SD of 10.5 and 9.09, which is statistically insignificant. Hypoglossal canal mean length 10.53 and 10.78 on right and left with SD $0.59 \& 0.7$ respectively, which is statistically insignificant. Forty six percent of the skulls studied exhibited an ovoid foramen magnum in their study. The average length of foramen magnum was $33.9 \pm 1.92 \mathrm{~mm}$ within a range of $30.9-35.5 \mathrm{~mm}$. The average length in the present study is comparable with the previous reports $[11,12]$.

\section{CONCLUSION}

The occipital condyles are integral part of neck and the base of skull. In the present study an effort was made to measure various parameters related to occipital condyle. These parameters should be taken into consideration during posterior and lateral approaches to the craniovertebral junction by neurosurgeons and orthopaedicians. These parameters will be helpful in interpreting the neurological investigative procedures and also in planning surgical interventions involving the skull base.

\section{Conflicts of Interests: None}

\section{REFERENCES}

[1]. Bulsara KR, Asaoka K, Aliabadi H, Kanaly C, Friedman A, Fukushima T. Morphometric three-dimensional computed tomography anatomy of the hypoglossal canal. Neurosurg Rev. 2008; 31:299302. [PubMed]

[2]. Gapert R, Black S, Last J. Sex determination from the foramen magnum: Discriminant function analysis in an eighteenth and nineteenth century British sample. Int J Legal Med. 2009; 123:25-33. [PubMed]
[3]. Nikumbh RD, Nikumbh DB, Karambelkar RR, Shewale AD. Morphological study of hypoglossal canal and its anatomical variation. Int J Health Sci Res. 2013; 3:54-8.

[4]. Karasu A, Cansever T, Batay F, Sabanci PA, Al-Mefty $O$. The microsurgical anatomy of the hypoglossal canal. Surg Radiol Anat. 2009; 31:363-7. [PubMed]

[5]. Avci E, Dagtekin A, Ozturk AH, Kara E, Ozturk NC, Uluc $K$, et al. Anatomical variations of the foramen magnum, occipital condyle and jugular tubercle. Turk Neurosurg. 2011; 21:18190. [PubMed]

[6]. Ozer MA, Celik S, Govsa F, Ulusoy MO. Anatomical determination of a safe entry point for occipital condyle screw using three-dimensional landmarks. Eur Spine J. 2011; 20:1510-7. [PMC free article][PubMed]

[7]. Naderi S, Korman E, Citak G, Güvençer M, Arman C, Senoglu M, et al. Morphometric analysis of human occipital condyle. Clin Neurol Neurosurg. 2005; 107:191-9. [PubMed]

[8]. Fathi Z, Ahmad I, Simmons J, Clark D, Loding A, Crow J. Surface Modification of Sodium Aluminosilicate Glasses using Microwave Energy: DTIC Document. 1992

[9]. Wen HT, Rhoton AL, Jr, Katsuta T, de Oliveira E. Microsurgical anatomy of the transcondylar, supracondylar, and paracondylar extensions of the farlateral approach. J Neurosurg. 1997; 87:555-85. [PubMed]

[10]. Brusati R, Pedrazzoli M, Colletti G. Functional results after condylectomy in active laterognathia. J Craniomaxillofac Surg. 2010; 38:179-84. [PubMed]

[11]. Muthukumar N, Swaminathan R, Venkatesh G, Bhanumathy SP. A morphometric analysis of the foramen magnum region as it relates to the transcondylar approach. Acta Neurochir (Wien) 2005; 147:889-95. [PubMed]

[12]. Wysocki J, Kobryn H, Bubrowski M, Kwiatkowski J, Reymond J, Skarzynska B. The morphology of the hypoglossal canal and its size in relation to skull capacity in man and other mammal species. Folia Morphol (Warsz) 2004; 63:11-7. [PubMed]

How to cite this article:

Jessy Rose George, Thomas Francis, Joseph Francis, Jeffy

Elizabeth Samuel. MORPHOMETRIC STUDY OF DRY HUMAN

OCCIPITAL BONE AND ITS CLINICAL RELEVANCE. Int J Anat Res

2019;7(1.2):6230-6233. DOI: 10.16965/ijar.2018.447 